\title{
Effect of Incorporation of Chips and Wood Dust Mahogany on Mechanical and Acoustic Behavior of Brick
} Clay

\author{
Gilbert Ganga', Timothee Nsongo², Hilaire Elenga ${ }^{2}$, Bernard Mabiala1, \\ Thomas Tamo Tatsiete ${ }^{3}$, Nzonzolo ${ }^{1}$ \\ ${ }^{1}$ Ecole Nationale Supérieure Polytechnique (ENSP), Université Marien Ngouabi, Brazzaville, Congo \\ ${ }^{2}$ Faculté des Sciences et Techniques, Université Marien Ngouabi, Brazzaville, Congo \\ ${ }^{3}$ Ecole Nationale Supérieure Polytechnique (ENSP), Université de Yaoundé I, Yaoundé, Cameroun \\ Email: ganga.gilbert@yahoo.fr, nsongo@yahoo.com
}

Received 19 April 2014; revised 1 July 2014; accepted 11 July 2014

Copyright @ 2014 by authors and Scientific Research Publishing Inc.

This work is licensed under the Creative Commons Attribution International License (CC BY). http://creativecommons.org/licenses/by/4.0/

c) (i) Open Access

\section{Abstract}

An experimental study was carried out on bricks using local materials in order to take into account the waste wood management to protect the environment and to reduce the cost of the habitat. Chips and sawdust were built-in clay bricks in order to study their influence on the compressive strength, Young's modulus and the speed for soundproofing. Testings in compressive strength were made on the parallelepiped clay bricks, stabilized with different percentages of cement, with incorporation to various percentages of sawdust or wood chips (Mahogany), using a universal press. Young's modulus was measured from the speed of sound by the ultrasonic method. The results obtained show that the incorporation of mahogany tree chips in the stabilized brick at $8 \%$ of cement, does not have much effect on the compressive strength. It was found that the incorporation of chips or sawdust on the clay brick, does not improve the compressive strength. The Young's modulus decreases with increasing content of sawdust and practically remains constant regardless of the content of chips at $4 \%$ and $6 \%$ of cement. The clay brick mixed with $8 \%$ of mahogany sawdust can be an acoustic barrier.

\section{Keywords}

Wood, Mahogany, Cement, Wood Chips, Sawdust, Compressive Strength, Young's Modulus, Speed of Sound, Clay Brick 


\section{Introduction}

Central Africa is a timber-producing sub-region. Wood industries generate a great quantity of waste woods that management has serious pollution problems. The use of waste wood in construction can be an alternative for the protection of the environment. The incorporation of wood waste in building materials has been the subject of several studies, most of which focused on the influence on the mechanical properties [1]-[3], on the mechanical properties of concrete. Meukam [4] has shown that stabilized ground bricks, incorporating sawdust present the better performances as regards to thermal isolation than those used currently in the houses construction. Taoukil et al. [5] have shown that the incorporation of the waste wood (sawdust or chip) reduces the concrete blocks of ground. Khelifi [6] has shown that the concretes' density decreases with the increase in the rate of the shavings; that the mechanical resistances of the concretes with chip untreated decrease in an important way compared to the concretes with the treated shaving. Mekhermeche [7] has shown in his study, that the ground bricks with 3\% of wood fibers (date palm) present an improvement of the heat and acoustic insulation of these materials. In this study, we focus on the comparative study of the influence of the chips and sawdust mahogany content on the compressive strength. We want to achieve an acoustic barrier to fight against noise using a maximum amount of wood waste and minimizing the cement content. The choice of mahogany is justified by its extensive use by the wood which releases huge waste. This study aims at contributing to the reduction of the environment pollution by the waste wood flarings. Our motivation of this study is based on the fact that we found no reference to previous work on the recycling of waste mahogany in Central Africa.

\section{Materials and Methods}

\subsection{Identification of Materials}

The materials were clay soil, cement, chips and sawdust mahogany and water.

- The earth material used for the manufacture of bricks was made at air atmosphere and various environment temperature. A mass of $6 \mathrm{~kg}$ of clay was used; this mass corresponds to 12 bricks at 3 samples per test and drying time. Clay used was taken at a depth of $2.5 \mathrm{~m}$, in suburbs located at the south-east of Brazzaville.

- The cement used for stabilization of clay is Portland cement CPA 45 which compressive strength at 28 days is $52 \mathrm{MPa}$. It consists of the clinker and the gypsum. The chemical composition of the clinker after cooking and that some gypsum is [8]:

Clinker: Silicate tricalcic (3CaO, $\left.\mathrm{SiO}_{2}\right)$ 50\% - 65\%; Silicate bicalcic (2CaO, $\mathrm{SiO}_{2}$ ) 15\% - 25\%; Aluminate tricalcic (3CaO, $\mathrm{Al}_{2} \mathrm{O}_{3}$ ) 8\% - 12\%; Alumino ferrite tétracalcic (4CaO, $\mathrm{Al}_{2} \mathrm{O}_{3}, \mathrm{Fe}_{2} \mathrm{O}_{3}$ ) 6\% - 10\%.

Gypsum: $\left(\mathrm{CaSO}_{4} \cdot 2 \mathrm{H}_{2} \mathrm{O}\right)$.

The compressive strength of concretes, mortars and blocks of stabilized earth is bound to the chemical composition of the binder.

- The quantity of industrial waste wood generated in Congo is very important and increase in the near future. The mahogany chips being a fibrous material the grading distribution of which spreads out between 0.5 and 20 $\mathrm{mm}$ [9]; [10] and the sawdust being in the form of small wood fibers of lower size grading in $0.8 \mathrm{~mm}$ [5], are materials lighter than the clay soil material used.

- The water content is determined by the Proctor: $22 \%$.

\subsection{Materials Used for the Test Tubes Manufacturing}

The experimental device manufacturing test is made up of the following components: a tank, a brick mould (Figure 1), a wooden device, a screed, a precision scale and a graduated cylinder and water from the BCBTP drilling, an electronic KERN KB scale type of the $(10,100 \mathrm{~g}$, $\mathrm{d}=0.1 \mathrm{~g})$ range, a trowel.

\subsection{Test of Compressive Strength}

The test for determining the compressive strength machine is a universal G.I.M. press brand (General Engineering Measurement), used according to the NF EN 196-1, the compressive force of $250 \mathrm{kN}$ (Figure 2). It is equipped with an indicator device which is constructed so that the previous value of the failure of the specimen is shown on the screen after returning to zero load. This may be achieved by using an indicator of a maximum pressure monitor or on a digital memory device (computer). The test machine, the charging is controlled manually, is provided with 

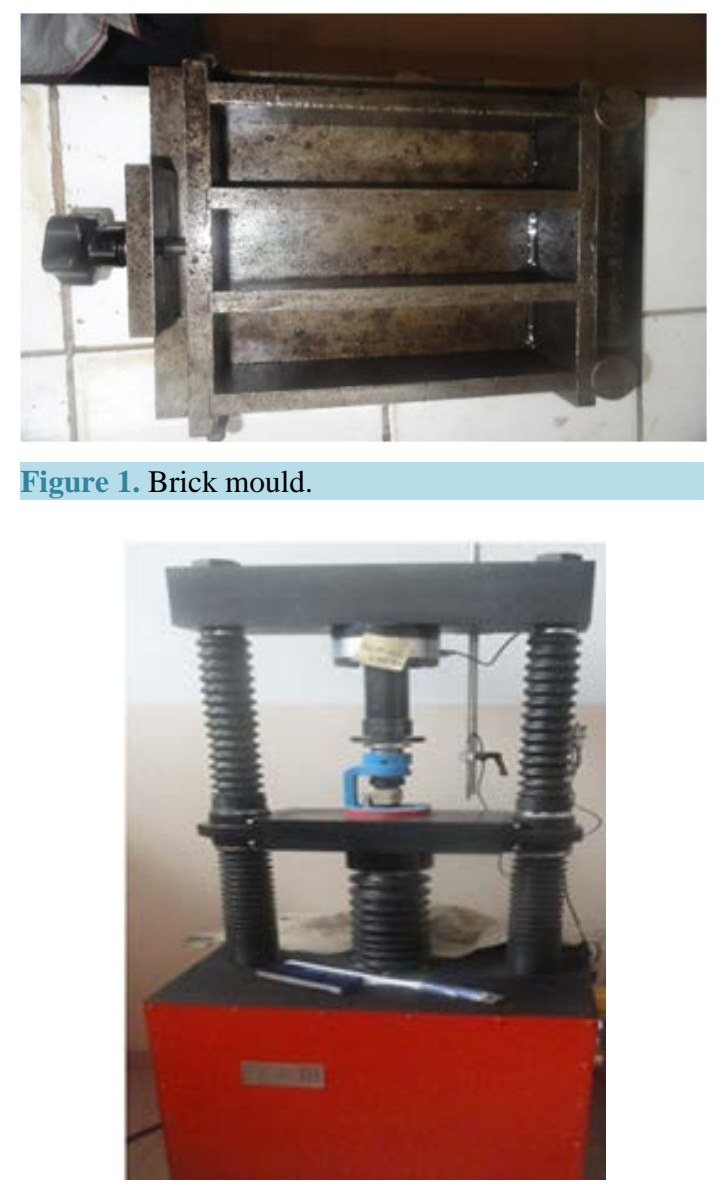

Figure 2. Universal press.

a measuring device controlling the loading speed.

\subsection{Materials Used for Measuring the Speed of Sound}

The experimental device of speed of sound measurement in the brick samples is made up of the following components: an ultrasound machine Pundit 7 (Figure 3), two ultrasonic convertors, one set of three cylinders, a ultrasound gel plug, and $16 \mathrm{~cm} \times 4 \mathrm{~cm} \times 4 \mathrm{~cm}$ small bricks size.

\section{Principle of the Method}

\subsection{Test Tubes Manufacturing}

By means of an electronic balance a mass of $6000 \mathrm{~g}$ of sieved clay, a mass of cement and a quantity of sawdust or chips of mahogany (as presented in Table 1) was weighed and poured into the tub of mixture; then by means of the trowel the mixture was mixed until have in few loan a homogeneous material. The mixture was moistened with $22 \%$ of water (1320 g) and still mixed. The mold was filled in 2/3 with the moistened material and was placed on the press; then a corresponding pressure chargeable to $75 \mathrm{KN}$ was exercised on the mold. The mold was removed from the press and before adding the material, the compacted coat was scarified; then we take back the operation. The cycle was repeated 3 times; and at the end of the third cycle, bricks was turned out and removed.

Bricks are then deposited on the clown of the laboratory where they are dried in the ambient temperature (Figure 4).

The size of bricks in the wet state are: length $16 \mathrm{~cm} \pm 0.02$; width $4 \mathrm{~cm} \pm 0.01$; height $4 \mathrm{~cm} \pm 0.01$; and volume about $256 \mathrm{~cm}^{3}$. 


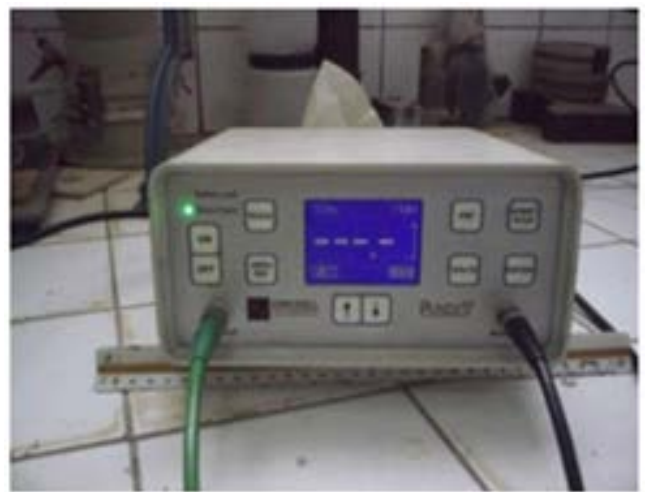

Figure 3. Pundit ultrasound device.

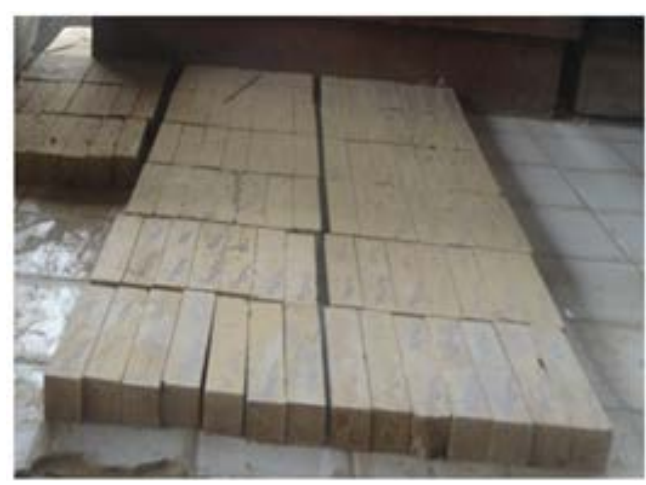

Figure 4. Brick samples.

Table 1. Mixture proportions for bricks.

\begin{tabular}{cl}
\hline M cement & \multicolumn{1}{c}{ Mixture proportions for bricks } \\
\hline $94 \%$ clay $+4 \%$ cement $+2 \%$ waste wood \\
$92 \%$ clay $+4 \%$ cement $+4 \%$ waste wood \\
$90 \%$ clay $+4 \%$ cement $+6 \%$ waste wood \\
$88 \%$ clay $+4 \%$ cement $+8 \%$ waste wood \\
$92 \%$ clay $+6 \%$ cement $+2 \%$ waste wood \\
$90 \%$ clay $+6 \%$ cement $+4 \%$ waste wood \\
$88 \%$ clay $+6 \%$ cement $+6 \%$ waste wood \\
$86 \%$ clay $+6 \%$ cement $+8 \%$ waste wood \\
$60 \%$ clay $+8 \%$ cement $+2 \%$ waste wood \\
$88 \%$ clay $+8 \%$ cement $+4 \%$ waste wood \\
$86 \%$ clay $+8 \%$ cement $+6 \%$ waste wood \\
$84 \%$ clay $+8 \%$ cement $+8 \%$ waste wood \\
\hline
\end{tabular}

\subsection{Compressive Strength Measurement}

Parallelepiped small bricks (3 samples per test and drying time) (Figure 4) are centered between the plates of the press and loaded continuously at an average speed of $0.20 \mathrm{MPa} / \mathrm{s}$ by a compressive force to crush. Calculating thereafter the compressive strength, which is the ratio between the compressive stress and the maximum section and the cross section of the crushed test device:

with 


$$
R_{C}=\frac{F_{C}}{S_{O}}
$$

$R_{C}$ : resistance to compression (MPa);

$F_{C}$ : maximum force pending compression $(\mathrm{N})$;

$S_{O}$ : initial area of the cross section of the test device before overwriting $\left(\mathrm{mm}^{2}\right)$.

\subsection{Speed of Sound Measurement}

Measuring the speed of sound through the measurement of propagation time of longitudinal wave. The principle of the experimental method is to generate an aural signal on one face of the sample and measure the propagation time of the longitudinal waves.

The two ultrasonic convertors are fixed to their support, the first is connected to the output CYLINDER (TRANS.) and the second output CYLINDER (REFLEC.) of the Pundit 7 device. Is selected the mode "TRANS." using the select switch, then one starts the ultrasonic operating. On ultrasound, it adjusts the intensity of the signal OUTPUT dB, amplification GAIN dB and the THRESHOLD, WIDE and SLOPE settings to be able to measure a signal propagation delay as large as possible without being overdriven.

Measurements are done in the following way:

- a thick gel layer on the ultrasound connection end faces of ultrasonic convertors is applied, then the convertors on the front part of the brick is pressed firmly;

- time $t$ from start of the transmit pulse at the beginning of the reception pulse is measured;

- it is 3 or 4 bars on the small brick moving converters, then are averaged and the results are set in a chart.

The same action on all small bricks is produced.

After the measurement of time, we determined the speed of sound by the following equation:

$$
V=\frac{L}{t}
$$

where $V$ is the speed of sound (m/s), $t$ time (s), and $L$ is the length of the sample (m).

\subsection{Young's Modulus}

Young's modulus is the constant that relates the tensile stress (or compression) and strain for an isotropic elastic material and is determined by Hooke's law:

$$
\sigma=E \cdot \varepsilon
$$

where: $\sigma$ is the stress (in units of pressure); $E$ is the Young's modulus (in units of pressure); $\varepsilon$ is the relative elongation or strain (dimensionless) (Figure 5).

The easiest way is to perform a tensile test and knowing the dimensions of the specimen, to deduce the Young's modulus $E$. However, it is difficult to make this measurement with good accuracy.

We can also measure the speed of sound in the material and deduce the Young's modulus. We have in this study used the ultrasonic test of measuring the speed of sound in the material to determine the Young's modulus. Ultrasonic testing is a very important non-destructive testing, which allows us to detect both several characteristics such as delay, the degree of compaction, the cracking rate [2].

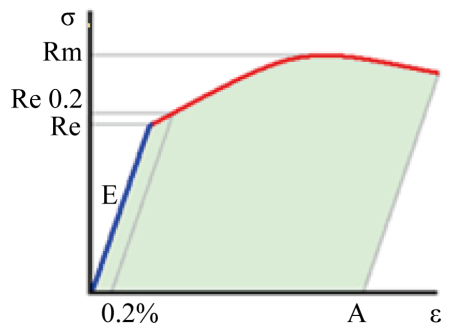

Figure 5. Stress-strain diagram (Young's modulus is determined over the initial linear portion). 
Measurement of Young's Modulus from the Speed of Sound in a Solid Body

The propagation speed is used in particular for determining the quality of concrete, for a faster propagation means that the concrete contains few air bubbles (the speed of sound in concrete is much higher than in air).

In a solid, the mechanical speed of the waves depends on $\rho$ density and constants of elasticity. The speed of sound is related to the elasticity relations parameters:

$$
\left\{\begin{array}{l}
C_{l}=\sqrt{\frac{E(1-v)}{\rho(1+v)(1-2 v)}} \\
C_{S}=\sqrt{\frac{E}{2 \rho(1+v)}}
\end{array}\right.
$$

where $E$ is Young's modulus, Poisson's ratio $v, \rho$ the density, $C_{l}$ speed $C_{S}$ and the longitudinal wave velocity of the transverse wave.

\section{Results and Discussion}

We made bricks at various contents of cement, sawdust and wood chips to study their influence on the mechanical and acoustic behavior by measuring the speed of sound.

The bricks are made up of parallelepiped shape and dimensions: $16 \mathrm{~cm} \times 4 \mathrm{~cm} \times 4 \mathrm{~cm}$, and were made with chips and dry sawdust untreated or pre-wet in the following proportions: Table 1.

The earth material used for the manufacture of bricks was steamed at $105^{\circ} \mathrm{C}$ for $24 \mathrm{~h}$ and then crushed and sieved (sieve module 34). A mass of $6 \mathrm{~kg}$ of land taken corresponds to 12 small bricks at 3 samples per test and drying time.

The water content is determined by the Proctor: $22 \%$.

The experimental results of compressive strength test determined by universal G.I.M. press brand are reported in Table 2 and Table 3.

\subsection{Influence of the Chips Content on the Compressive Strength}

Figure 6 shows the compressive strength variation with mahogany chips content at different cement content. The compressive strength decreases with increasing content of chips to $4 \%$ cement; it passes through a minimum of $6 \%$ of cement and up to $8 \%$.

\subsection{Influence of the Content of the Sawdust on the Compressive Strength}

In Figure 7, we have shown the variation of compressive strength with mahogany sawdust content at different cement contents. At $8 \%$ cement, the results show a minimum and a maximum, then a minimum of $4 \%$. We noted

Table 2. Experimental compressive strength of the tested clay brick samples at 28 days.

\begin{tabular}{cccccccccccc}
\hline & \multicolumn{1}{c}{ \% C.M } & \multicolumn{8}{c}{ Compressive strength [MPa] } \\
& & $0 \%$ & $\begin{array}{c}\text { SD (standard } \\
\text { deviation) }\end{array}$ & $2 \%$ & $\begin{array}{c}\text { SD (standard } \\
\text { deviation) }\end{array}$ & $4 \%$ & $\begin{array}{c}\text { SD (standard } \\
\text { deviation) }\end{array}$ & $6 \%$ & $\begin{array}{c}\text { SD (standard } \\
\text { deviation) }\end{array}$ & $8 \%$ & $\begin{array}{c}\text { SD (standard } \\
\text { deviation) }\end{array}$ \\
\hline $4 \%$ & 9.26 & 1.712 & 4.95 & 0.269 & 4.18 & 0.300 & 3.95 & 0.622 & 3.55 & 0.272 \\
$6 \%$ & 10.42 & 2.481 & 4.07 & 0.556 & 4.96 & 0.727 & 5.48 & 0.449 & 5.06 & 0.447 \\
$8 \%$ & 12.86 & 0.949 & 12.62 & 2.216 & 13.72 & 0.521 & 12.35 & 0.285 & 11.56 & 2.947 \\
\hline
\end{tabular}

Table 3. Experimental compressive strength of the tested clay brick samples at 28 days.

\begin{tabular}{cccccccccccc}
\hline & $\%$ S.M & \multicolumn{8}{c}{ Compressive strength [MPa] } \\
\cline { 2 - 9 }$\%$ & $0 \%$ & $\begin{array}{c}\text { SD (standard } \\
\text { deviation) }\end{array}$ & $2 \%$ & $\begin{array}{c}\text { SD (standard } \\
\text { deviation) }\end{array}$ & $4 \%$ & $\begin{array}{c}\text { SD (standard } \\
\text { deviation) }\end{array}$ & $6 \%$ & $\begin{array}{c}\text { SD (standard } \\
\text { deviation) }\end{array}$ & $8 \%$ & $\begin{array}{c}\text { SD (standard } \\
\text { deviation) }\end{array}$ \\
\hline $4 \%$ & 9.26 & 1.712 & 4.31 & 0.736 & 4.66 & 0.413 & 5.22 & 0.608 & 5.16 & 0.766 \\
$6 \%$ & 10.42 & 2.481 & 5.94 & 0.467 & 5.05 & 0.964 & 5.01 & 0.595 & 4.88 & 1.134 \\
$8 \%$ & 12.86 & 0.949 & 12.03 & 0.910 & 13.45 & 0.678 & 11.63 & 0.926 & 8.52 & 1.845 \\
\hline
\end{tabular}




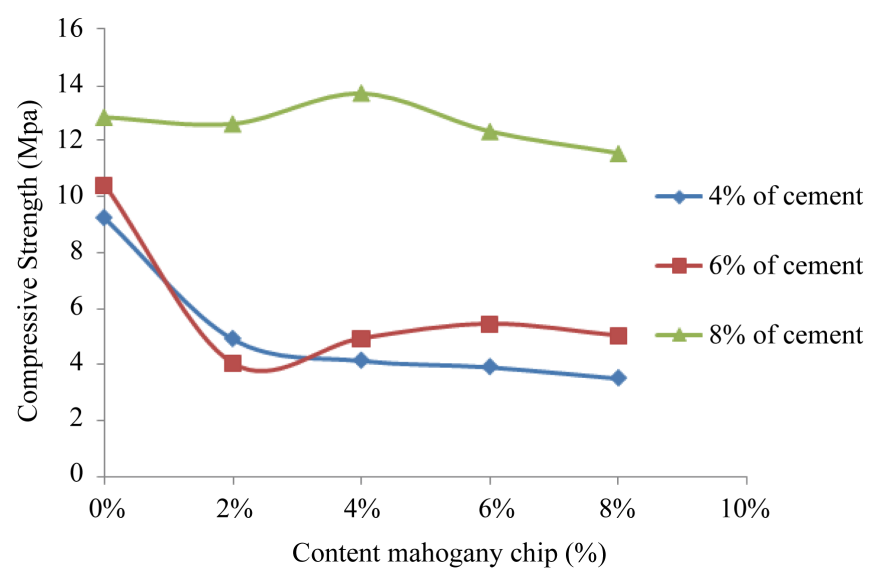

Figure 6. Variation in compressive strength as a function of content chips.

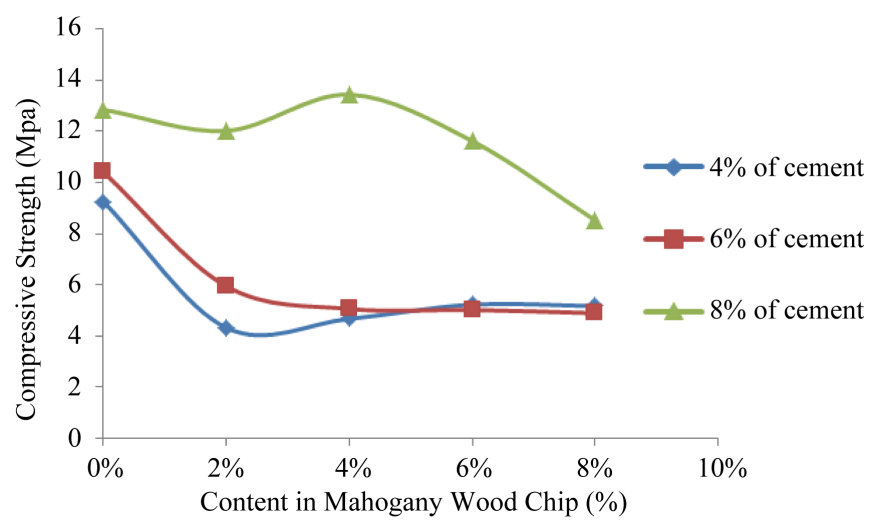

Figure 7. Change in compressive strength as a function of content sawdust.

that the compressive strength decreases with increasing the content of sawdust to $6 \%$ cement.

The results show that the incorporation of sawdust or shavings mahogany does not improve the compressive strength. This result is consistent with that reported in the literature [6].

\subsection{Study of the Compressive Strength Evolution as Function of Brick Age}

We studied the effect of age on the brick compressive strength. We represented the results in Figure 8 and Figure 9. We observe that the compressive strength increases with the age of the brick whatever content chips or sawdust. This resistance varies very little for mahogany's chips at $6 \%$ cement but exhibits the same behavior for chips and sawdust to $4 \%$ cement.

\subsection{Influence of Sawdust and Chips Content on the Young's Modulus}

Table 4 and Table 5 present the values of the Young's modulus determined by calculation using the following relation (3):

$$
C_{l}=\sqrt{\frac{E(1-v)}{\rho(1+v)(1-2 v)}}
$$

We have analyzed the Young's modulus variations regarding the sawdust and chips' content.

The obtained results are shown in Figure 10 and Figure 11. These results show that the Young's modulus decreases with the increase of the sawdust content and remains virtually constant regardless the chips' content at $6 \%$ cement. 


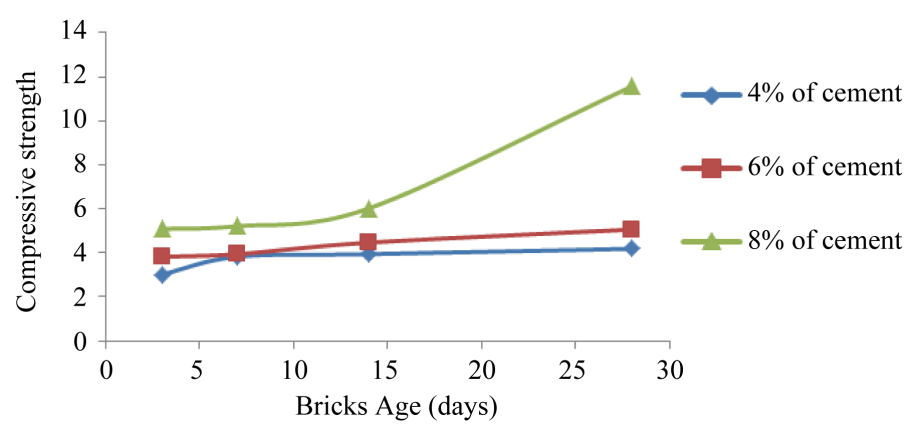

Figure 8. Variations of strength compressive brick at 8\% mahogany wood chips in accordance with the age of the brick.

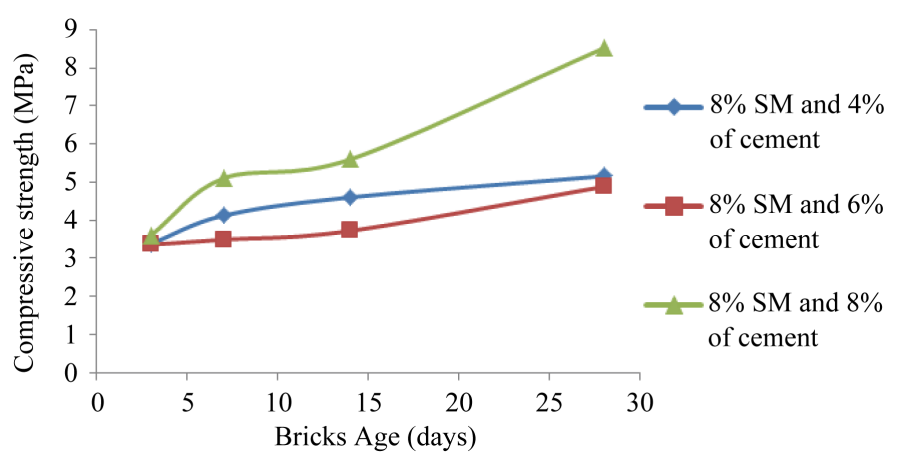

Figure 9. Variations of strength compressive brick at $8 \%$ mahogany sawdust in accordance with the age of the brick.

Table 4. Young's modulus for clay brick samples stabilized with $4 \%$ cement at 28 days as a function of waste wood mahogany content.

\begin{tabular}{ccc}
\hline \multirow{2}{*}{$\begin{array}{c}\text { Percentage } \\
{[\%]}\end{array}$} & \multicolumn{2}{c}{ Young's modulus at 4\% cement [GPa] } \\
\cline { 2 - 3 } $2 \%$ & Sawdust of mahogany & Chips of mahogany \\
$4 \%$ & 0.253 & 0.231 \\
$6 \%$ & 0.249 & 0.195 \\
$8 \%$ & 0.245 & 0.191 \\
\hline
\end{tabular}

Table 5. Young's modulus for clay brick samples stabilized with 6\% cement at 28 days as a function of waste wood mahogany content.

\begin{tabular}{ccc}
\hline $\begin{array}{c}\text { Percentage } \\
{[\%]}\end{array}$ & \multicolumn{2}{c}{ Young's modulus at 4\% cement [GPa] } \\
\cline { 2 - 3 } $2 \%$ & Sawdust of mahogany & Chips of mahogany \\
\hline$\%$ & 0.293 & 0.221 \\
$6 \%$ & 0.231 & 0.222 \\
$8 \%$ & 0.219 & 0.224 \\
\hline
\end{tabular}

\subsection{Influence of Contents and Sawdust Shavings on the Speed of Sound}

We have measured the speed of sound for different contents of sawdust and wood chips to determine the variability effect in the content of mahogany shavings and sawdust on the acoustic properties. Table 6 and Table 7 present the speed of sound of different clay brick samples.

For bricks that the cement content is 6\%, the sound velocity shown in Figure 12, is greater for the chips and 


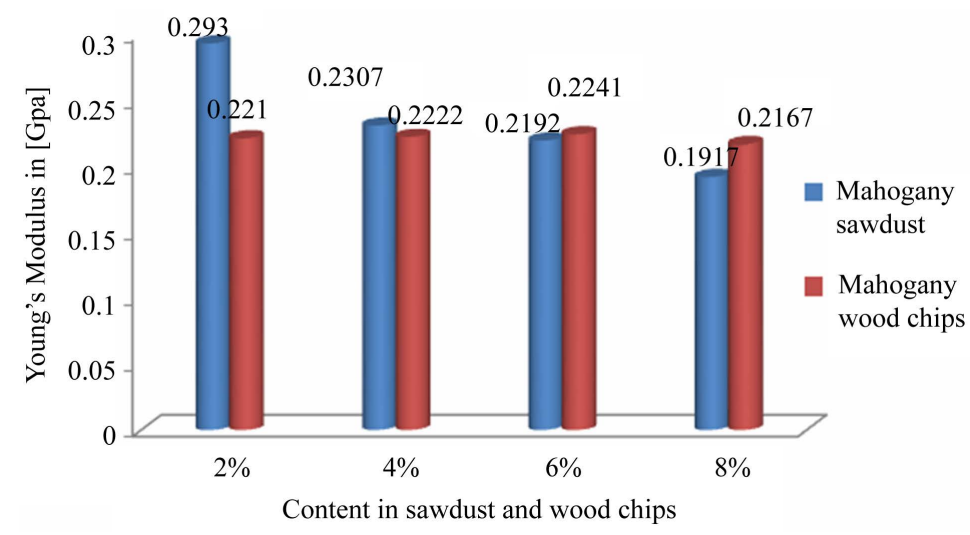

Figure 10. Young's modulus of $6 \%$ cement bricks.

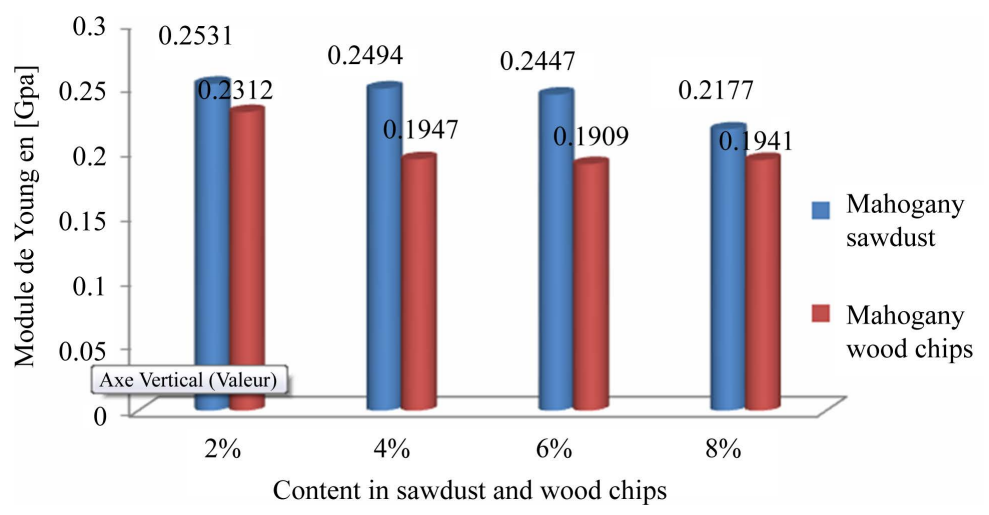

Figure 11. Young's modulus of $4 \%$ cement bricks.

Table 6. Sound's speed for clay brick samples stabilized with $4 \%$ cement at 28 days.

\begin{tabular}{ccc}
\hline \multirow{2}{*}{$\begin{array}{c}\text { Percentage } \\
{[\%]}\end{array}$} & \multicolumn{2}{c}{ Sound's speed at $4 \%$ cement $[\mathrm{m} / \mathrm{s}]$} \\
\cline { 2 - 3 } & Sawdust of mahogany & Chips of mahogany \\
\hline $2 \%$ & 1786.04 & 1691.73 \\
$4 \%$ & 1782.78 & 1592.74 \\
$6 \%$ & 1772.85 & 1594.14 \\
$8 \%$ & 1706.13 & 1606.67 \\
\hline
\end{tabular}

Table 7. Sound speed for clay brick samples stabilized with $6 \%$ cement at 28 days.

\begin{tabular}{ccc}
\hline \multirow{2}{*}{$\begin{array}{c}\text { Percentage } \\
{[\%]}\end{array}$} & \multicolumn{2}{c}{ Sound speed at $6 \%$ cement $[\mathrm{m} / \mathrm{s}]$} \\
\cline { 2 - 3 } $2 \%$ & Sawdust of mahogany & Chips of mahogany \\
\hline $4 \%$ & 1890.67 & 1672.29 \\
$6 \%$ & 1689.60 & 1695.02 \\
$8 \%$ & 1688.53 & 1707.84 \\
\hline
\end{tabular}

passes through a maximum regardless of the chip content higher than $2 \%$.

We also noted a noticeable difference in the speed of sound for contents of $8 \%$ in chips and sawdust of mahogany. 


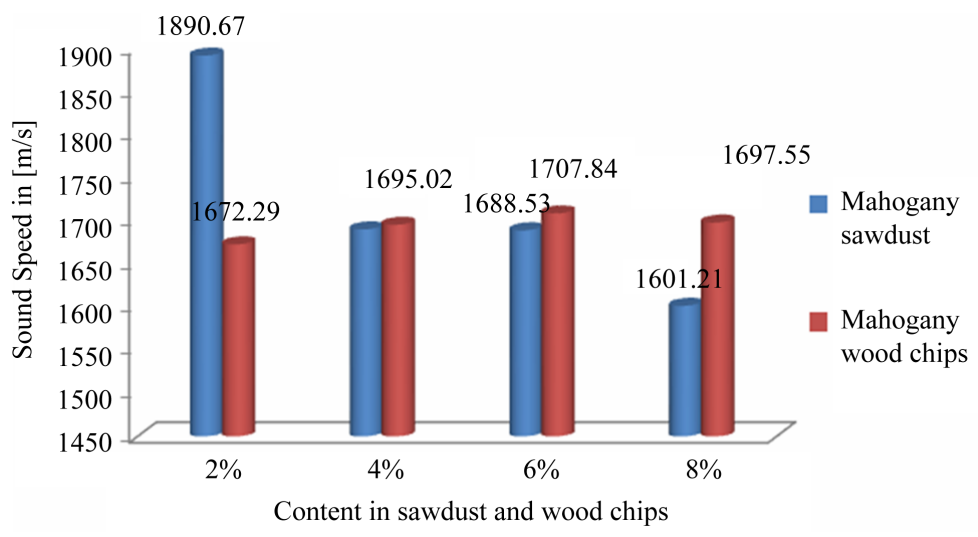

Figure 12. Speed variations of sound in the bricks made up of $6 \%$ cement related to the content of sawdust and wood chips after 28 days.

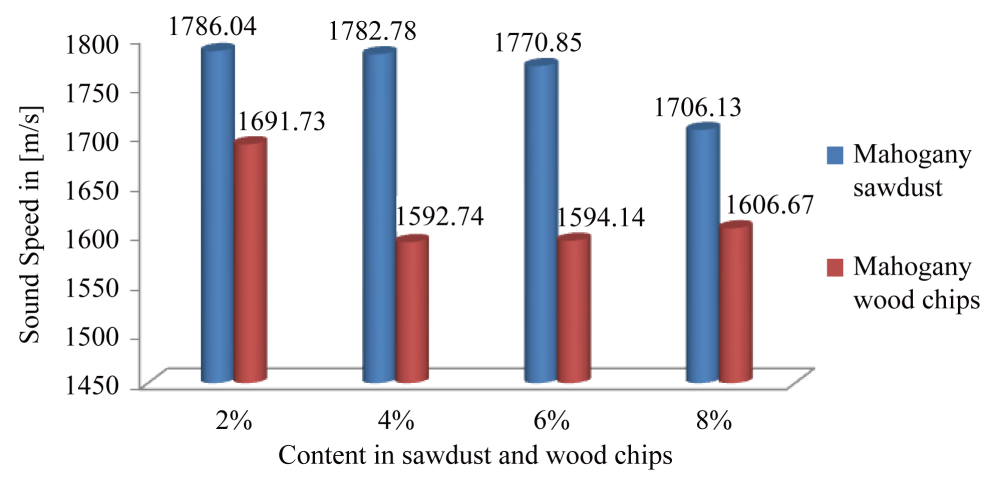

Figure 13. Speed variations of sound in the bricks made up of $4 \%$ cement related to the content of sawdust and wood chips after 28 days.

For bricks that the cement's content is $4 \%$ (Figure 13), the situation is reversed.

\section{Conclusions}

We have studied the effect of the incorporation of the mahogany tree waste on the clay brick and the study has revealed the following conclusions:

- Incorporation of the wood shavings or sawdust in the clay brick does not improve the compressive strength. We however note that the compressive strength slightly varies with the content of mahogany chips when the clay brick is stabilized at $8 \%$ with cement;

- The elastic modulus decreases with increasing content of sawdust and remains substantially constant regardless of the content of chips at $6 \%$ of cement;

- The speed of sound shows up a maximum between $4 \%$ and $6 \%$ of content in chips or sawdust.

This result reveals a correlation between the amount of wood residues and the acoustic properties of the brick.

Waste wood can be used as an acoustic barrier for high sawdust or chips grades.

\section{References}

[1] Ganga, G. (2013) Impact of Waste Wood on the Mechanical and Acoustic Properties of Stabilized Mud Bricks. Master Thesis, University of Yaounde I, Yaounde.

[2] Nzabana, A. (2013) Study of the Influence of the Content of the Shavings and Sawdust Mahogany Stresses and Strains on the Brick Clay during Drying in the Open Air and in the Oven. Master Thesis, University Marien Ngouabi, Brazzaville.

[3] Gaye, S. (2001) Characterization of Mechanical, Acoustic and Thermal Properties of Local Building Materials in Senegal. Thesis Status of Science, University Cheikh Anta Diop, Dakar. http://www.sist.sn/gsdl/collect/butravau/ 
[4] Meukam, P. (2004) Characterization of Local Materials for the Thermal Insulation of Buildings. PhD Thesis, University of Yaounde I, Yaounde. http://www.u-cergy.fr//theses/04CERG0287.pdf

[5] Taoukil, D., et al. (2011) Mechanical Characterization and Water with a Lighter Wood Waste Concrete. International Journal of Solar Technology, 43, 1-7. http://www.comples.org/43_Taoukil.pdf

[6] Belouettar, K.W.R. (2012) Influence of the Nature of the Wood Chips on the Physical and Mechanical Properties of Concrete Made from Wood Chips. Twentieth Meeting of Civil Engineering University, 6-8 June 2012. http://www.polytech.univ-savoie.fr/fileadmin

[7] Mekhermeche, A. (2012) Contribution to the Study of Mechanical and Thermal Properties of Bricks i Earth with the Aim of Their Use in the Restoration of Saharan Ksour. Memory of Magister in Civil Engineering. University Kasdi Merbah Ouargla, Ouargla.

[8] Hydraulic Binders on: http://iut-tice.ujf-grenoble.fr/tice-espaces/GC/matériaux

[9] Tamba, S., Voumbo, M.L., et al. (2007) Durability of Lightweight Concrete Made of Wood Chips. Journal of Science, 7, 67-72. http://www.cadjds.org/media1/JDSV7N4

[10] Pehanich, L.J., Blankenhom, P.R. and Silsbee, M.R. (2004) Wood Fiber Surface Treatment Level Effects on Selected Mechanical Properties of Wood Fiber Cement Composite. Cement and Concrete Research, 34, 59-65. http://dx.doi.org/10.1016/S0008-8846(03)00193-5

\section{Nomenclature}

BCBTP: Bureau de Contrôle des Bâtiments et Travaux Publiques

SM: Sawdust of Mahogany

WCM: Wood Chips of Mahogany 
Scientific Research Publishing (SCIRP) is one of the largest Open Access journal publishers. It is currently publishing more than 200 open access, online, peer-reviewed journals covering a wide range of academic disciplines. SCIRP serves the worldwide academic communities and contributes to the progress and application of science with its publication.

Other selected journals from SCIRP are listed as below. Submit your manuscript to us via either submit@scirp.org or Online Submission Portal.
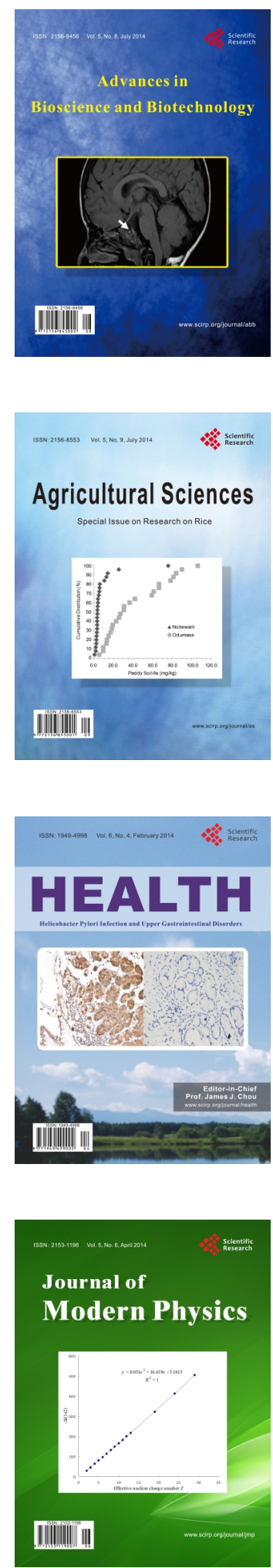
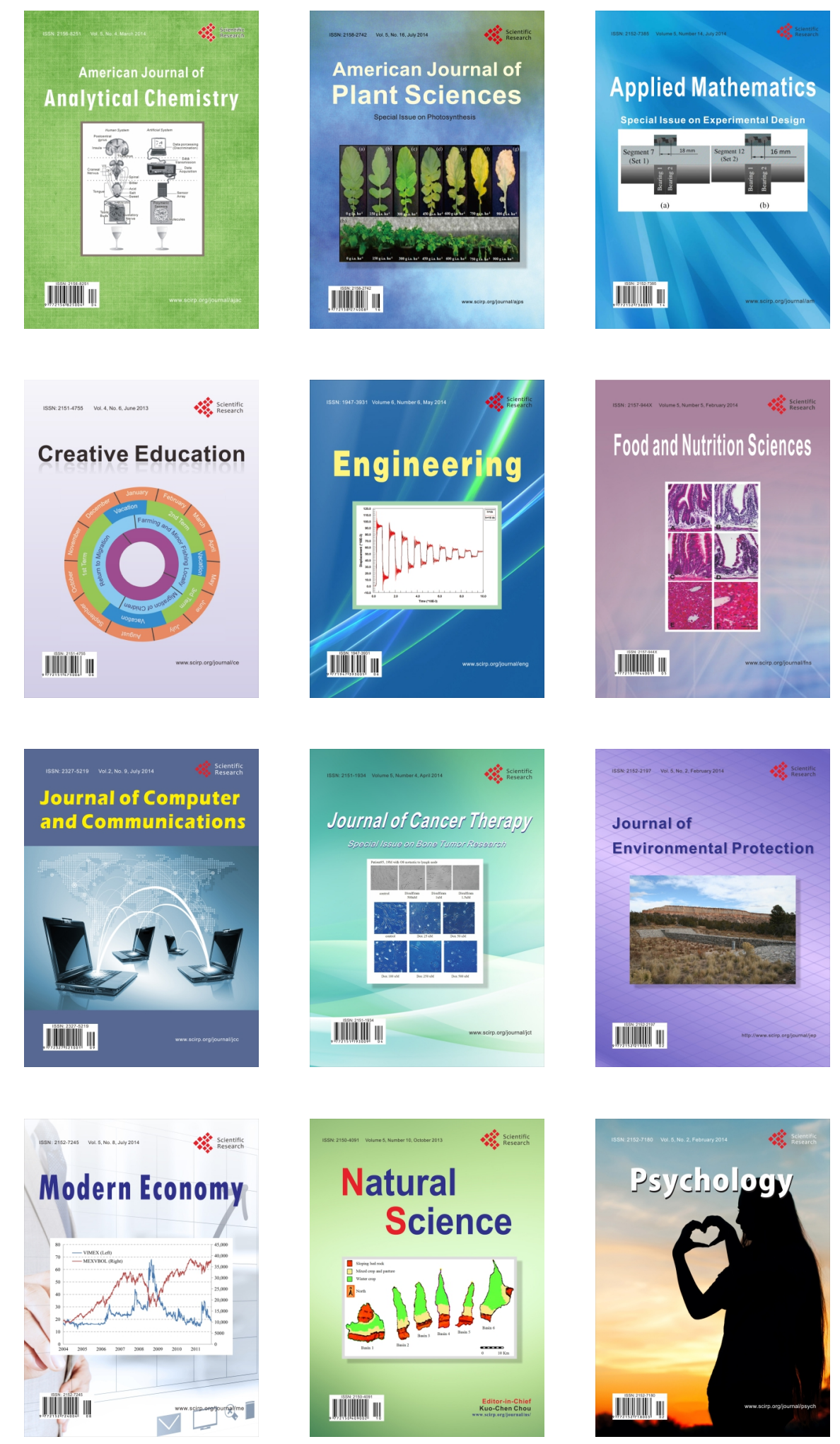